\title{
Re-thinking reading from institutions, subjects and identity
}

\section{Re-pensar la lectura desde las instituciones, los sujetos y la identidad}

JASSO-VELÁZQUEZ, David†*, VILLAGRÁN-RUEDA, Sonia, RODRÍGUEZ-ORTIZ, Mónica and ALDABA-ANDRÁDE, María Dolores

Universidad Autónoma de Zacatecas. Jardín Juárez 147, Centro Historico, Zacatecas Centro, 98000 Zacatecas, Zac.

ID $1^{\text {st }}$ Author: David, Jasso-Velázquez / ORC ID: 0000-0002-8289-150X, CVU CONACYT ID: 864842

ID $1^{\text {st }}$ Coauthor: Sonia, Villagrán-Rueda / ORC ID: 0000-0001-5389-574X, CVU CONACYT ID: 737274

ID $2^{\text {nd }}$ Coauthor: Mónica, Rodríguez-Ortiz / ORC ID: 0000-0001-8268-1193

ID $3^{\text {rd }}$ Coauthor: María Dolores, Aldaba-Andráde / ORC ID: 0000-0002-3176-1115, CVU CONACYT ID: 946038

DOI: $10.35429 / J E H .2019 .5 \cdot 3.1 .13$

Received July 28, 2019; Accepted December 19, 2019

\begin{abstract}
La pregunta es frecuente; ¿Para qué es leer? Las respuestas más obvias podrían ser: leer es inútil, cuando se disfruta de la lectura, leer es un acto libre, ganar bien y ser aceptado socialmente, no es necesario leer libros, dar libros es regalar obligaciones. Algunas de estas respuestas nos invitan y nos animan a leer, otras desvinculan completamente la lectura de la vida cotidiana. Es por eso que debemos pensar en qué idea de leer el Sistema Educativo Mexicano está ofreciendo a los estudiantes. A los estudiantes (de cualquier nivel educativo) se les promete que acercarse a los libros los hará grandes e importantes en el futuro; Parece que el sujeto no encuentra una recompensa. La única razón por la que los temas pueden estar interesados en un libro es la dimensión mágica de su contenido; Todo lo demás comienza por ser un discurso del deber y un acto aborrecible.
\end{abstract}

Reading, Subjects, Identity

\begin{abstract}
Resumen
The question is frequent; What is reading for? The most obvious answers could be: reading is useless, when reading is enjoyed, reading is a free act, to earn well and be socially accepted, it is not necessary to read books, giving books is giving away obligations. Some of these answers invite us and encourage us to read, others completely unlink the reading of everyday life. That is why we should think about what idea of reading the Mexican Education System is offering students. Students (of any educational level) are promised that approaching books will make them great and important in the future; It seems that the subject does not find a reward. The only reason why subjects can be interested in a book is the magical dimension of its content; Everything else begins by being a speech of duty and an abhorred act.
\end{abstract}

Lectura, Sujetos, Identidad

Citation: JASSO-VELÁZQUEZ, David, VILLAGRÁN-RUEDA, Sonia, RODRÍGUEZ-ORTIZ, Mónica and ALDABAANDRÁDE, María Dolores. Re-thinking reading from institutions, subjects and identity. RINOE Journal-Economic History. 2019. 3-5: 1-13.

\footnotetext{
* Correspondence to Author (email: dajass971@gmail.com)

$\dagger$ Researcher contributing first author.
} 


\section{Introduction}

The question is frequent; What is reading for? The most obvious answers could be: reading is useless, when reading is enjoyed, reading is a free act, to earn well and be socially accepted, it is not necessary to read books, giving books is giving away obligations. Some of these answers invite us and encourage us to read, others completely unlink the reading of everyday life. That is why we should think about what idea of reading the Mexican Education System is offering students.

Students (of any educational level) are promised that approaching books will make them great and important in the future; It seems that the subject does not find a reward. The only reason why subjects can be interested in a book is the magical dimension of its content; Everything else begins by being a speech of duty and an abhorred act.

The following questions as points of reflection are answered throughout the document: Why do governments and their public policies emphasize the training of readers? And why do most of the occasions and official voices fail in their persistent attempt to make crusades in favor of reading? What role do institutions play in shaping reading subjects?

This chapter aims to provide the reader with tools to rethink reading from theoretical constructs: subject, identity and institution. Therefore, manifest elucidation is centered on a theoretical reflection on the conformation of the reading act.

In this way, it is necessary to conceive the reading practices and reason them from the people, from the social, cultural and political lineage of which one is subject. Explain and understand reading as a practice allows you to position yourself and become critical and purposeful agents. If the teachers of the different educational levels are not convinced of this process of reflection, it is possible that they continue to develop instrumental reading practices, of the school and for the school only. It should be noted that the instrumental, in this context, is understood as the implementation of mechanical reading or by obligation, and not as a practice embodied in subjectivity.
There is no attempt to demonize instrumental reading, because at some point it has been read only by obligation and by satisfying work or school needs, the idea that the individual consolidates a reading habit according to reading experiences is justified.

\section{Tools to rethink reading: subjects and institutions}

Without theoretical tools it is impossible to think with analytical rigor, which is why it is crucial when making a critical and creative rereading of everything that implies the constitution of the reader when using the notions of subject and institution. In this sense, the subjectivation game is referred to as a strategy of reconceptualization of the subject beyond a self-absorbed subjectivity, but also, beyond, of a solipsist individuality. The terms, subject, subjectivity and institution, become relevant, are part of the theory that attempts to explain the specific situation of reading practices in the school and extracurricular context. It should be noted that they have been difficult concepts to analyze and even more to define them. Each of the above concepts, receives different meanings depending on the situation, context or interest of those who use them to explain this or that social phenomenon.

In the same sense, the study approach of "reading practices" guides the application and interpretation of the concepts of subject, subjectivity and institution. This section begins by explaining and interpreting the concept of institution to understand how reading practices are developed precisely in institutions, and in particular from the loop that is constituted between institution (instituted power) and social subjectivity (instituting power).

Institutions are part of everyday life. As social subjects we specify them day by day, we are subject to them; likewise our subjectivity makes them distinguish and interpret and live differently. Most educational research, take as a starting point, to achieve their purposes, the analysis of various institutions, and consider as a nodal point that makes them possible from their links, interrelations, habits, hobbies, customs, what does or stops doing: the subject. Subjectivity configures a mapping of human intentions and searches. 
On the other hand authors like; Lapassade (1977) and René Laurou (1970) present an analysis of the institutions, from which one can understand the complexity, which goes beyond an infrastructure or building, and the relationships that are generated within them. Institutions are official social groups, companies, schools, unions and the systems of rules that determine the life of these groups. Institutions are a set of fully instituted acts or ideas that men find in front of them and that are imposed to a greater or lesser extent.

Therefore, institutions are considered as organizations, structures, social relationships, etc., reading is immersed in institutions and at the same time is an institution, because it is based on the subject's relationship with practice. There is difficulty in defining institutions because there are materialized (concrete) and not physical (abstract), the former can be defined as visible, as a system; the non-physical ones are the symbolic ones such as language, marriage, divorce, that is, the symbolic ones are those that are not materialized but that determine and consolidate the social role. Institutions are systems of rules, set of acts or ideas fully instituted, the essence of these focuses on the interpersonal relationships that are configured. The definition and analysis of the concept of institution is justified by recognizing that the practice of reading is an activity that is generated within an institution, be it called family, school or groups of friends, it is the institutions that legitimize reading (Merlo, 2007 ). Laurou (1970) states that all institutions have elements in common, or universal, however, these common elements may be different when the same groups that make up society change the social function; It is here when the peculiarities arise. Universals are defined as units that bear close resemblance. This is a first feature. The universals do not incarnate directly in the individuals they go through the mediation of singular social forms, of forms of organization more or less adapted to one or several functions. Under this perspective, there is a historical apriori of the universals, that is, for Laurou the universals do not vary, they remain the same regardless of the context. This position could be questioned, because everything that is developed in the social sphere is subject to change. Otherwise, for example, what happens with the law of gravity, is understood in America and in China, that Law is universal.
In society, laws, which Laurou considers universal, tend to change according to the political-social context in which they are situated. In that sense all societies have laws and norms, however, in all they are different. The practice of reading, could be considered as a universal, since in all institutions they are consolidated to a greater or lesser extent, from this perspective it is interpreted that in all cultures reading practices are established, however, in all of them differently this phenomenon, influenced by the cultural-social environment. Also, I could not say that there is only one type of universal reader; If the reading is as a form of interpretation mediated by the subjectivity of the subject, there will be many types of readers. In that sense, institutions are just empty forms whose universality is insignificant because each society fills them in different ways.

In this sense, Laurou (1970) manifests his idea about universals and asserts that knowing and understanding these is relevant to understand institutional social dynamics; affirms that some of the universals that all institutions keep are: norms and values, social and symbolic forms; acts, actions or social relationships in different contexts and roles, always seek to educate the subject, are regulated, establish hierarchy, internalize role models, integrate their users into the total system, one of the first functions is to produce profit (profit is justified by the need to satisfy wishes, demand and consumer preferences).

However, if a critical attitude is adopted, in the face of these arguments, it is concluded that universals are not static, are malleable, changing according to the type of society. In that sense, if reading practices are considered as universals of educational institutions, an uncritical stance would be evident, since as Paolo Virno (2004) affirms, there are no absolute universals. Although reading is carried out in all educational institutions, it does not always read the same, the focus of reading practices may change according to the subjectivity and ideology of the reading social subject. In any case, reading has never existed as a universal and immutable entity, but rather it has to be read as a socio-historical and political practice located in a defined context. 
Thus, in all institutions, there are ways to bring or close subjects to reading, however, in all of them the process is constituted differently. Although the ways of legitimizing reading practices are different, the results are almost always the same; rigid and limited reading practices are generated, a purely academicist idea of reading is encouraged (Merlo, 2007). Laws and regulations, for example, exist in all institutions, however, a family or educational institution in Hong Kong has different rules from those of a Mexican family or educational institution, and these vary according to the social, political, cultural context and even the economic one, despite this the end is not dissimilar, it is about regulating the subject, of taking it along a certain path.

Based on the foregoing, and taking up the vision of Lourau (1970), it is concluded that all institutions seek from a "must be" to be internalized in the individual, or person as subject and actors. However, at birth there are internalized institutions that could well be called inheritance, an example of this is language, incest and parental relationships. These institutions allow in turn the integration of other more complex ones in the existing hierarchy, and the one that fails to consolidate the inheritance institutions can be considered a social mismatch, since it will not be regulated, will not follow the established rules and will break with the established relations and accepted by the social structure. Reading cannot be considered an inheritance institution, because if there are more than two or three "illiterate" members in the family, they are not considered misfits. And the fact is that reading is totally embedded in the organization and social conditions. The initiative of the reading, the representations of the book and of the reading act in the frame of the networks of socialization. For its part, Lapassade (1977) makes an analysis of pedagogical institutions, and classifies them into internal and external. The first refers to the structural and regulated dimension of the exchanges (time of entry, exit), to the set of institutional techniques that can be used in the class: teamwork, council, etc. Pedagogical institutions external to the pedagogical structures outside the classroom, the social group of the class that are part, the academy, the programs, the regulations have been called. In pedagogical institutions, whether internal or external - as Lapassade classifies them - there is something specific related to reading, you have to think about how and in what way readers are forged.
A reading subject is not exactly the one who reads a lot, but a reading subject may be the one who reads little, but is able to re-signify his life, his experience and his imagination. That is, the system or institutions - seen from what the theorists explain - form a type of reading subject that can read a lot or a little; but they can also form a subject that, as we said, can load 6 to 8 books a day, but is not therefore a reader; the difference is that you can have the books, but read them from an instrumental perspective, by mere school obligation.

Therefore, it is considered that the knowledge of the external institutional system implies, therefore, that of the bureaucratic organization of education. Lapassade (1977) called a pedagogical bureaucracy to a social structure in which: the fundamental decisions are taken within a hierarchical system, at the central level the bureaucracy exercises power, rules that define statutes, functions, obligations, sanctions are produced. The difference between bureaucracy and teaching activity is that the teacher forms and transforms objects, in this case to children and, bureaucratic activity does not transform anything; Control the transformation. External and internal institutions, as Lapassade (1977) names them, are an important point of analysis to study how reading is considered and what is done to encourage or institutionalize reading practices in students.

In this sense, the official documents and public policies governing the forms and modes related to the development of reading practices are considered as external institutions; for example, the Basic Education Study Plans and Programs (SEP, 2009), official PISA documents (PISA 2006 Scientific competences for the world of tomorrow: Scientific competences for the world of tomorrow, 2008) and OECD (2011), programs Education responsible for promoting reading, as is the case of the "National Reading Program" (SEP, 2001), previously known as "Reading Corners", or even public policies such as "Towards a Country of Readers" (2004) . There is a palpable disconnection between external institutions (curriculum and educational policies) and internal institutions (teaching practices). The curriculum and educational policies that attempt to regulate the training of students do not regulate the training of teachers. 
And this situation is a problem, because teachers without knowing the epistemological foundations of the reading proposals offered by the bureaucracy, apply them based on what he manages to interpret and his criteria, which is why the National Reading Program - Applied in elementary schools, it has failed to fully meet its objectives. To train students as reading subjects, you would first have to train reading teachers.

That is why, in order to organize pedagogical institutions, whether internal or external, it is necessary to make an institutional analysis that goes far beyond the mere aspiration to produce a new relationship with knowledge, an awareness of non-knowledge that determines our action, it would be necessary to recreate the institutional space as a cartography that at the same time is a product and (re) producer of creative games or subjectivation reagents.

In this way, the analysis of the institutions as a study of them from the plots of meanings that are generated in the subjects to carry out a certain social practice, is necessary to understand in its complexity the phenomenon of the practice of reading. Regarding the institutions, Ida Butelman (1994), affirms that the concept of institution is not uniform or univocal, but that it is polysemic and therefore has multiple meanings that depend on the contents that societies of all cultures add to it. Despite its different meanings, Ida Butelman, continues to adopt some universals to define the term of institution:

a) General rules or regulations system.

b) Social structure or organization.

c) Place of production and production relations.

That is why education is therefore defined as an institution in a body of indications, regulations and general norms, emerged throughout the history of society from the spontaneous repetition of actions. Butelman (1994) asserts that educational institutions are always in search of their completion, because they are in a permanent state of non-completion and this is what produces the universal permanence of education as an institution.
This idea of Butelman, seen from a critical perspective, is somewhat trivial, since all institutions are incomplete and are constantly searching for completion. Likewise, institutions are always manifesting contradictions. An example of this is the educational institutions, where it is necessary to ensure that the "child appropriates content" that will later serve to solve challenges that may arise in their daily lives, however, when the child is not able to regulate and learn contents, the intervention of psychotherapists, psychopedagogues, etc., is proposed, solve the problem that the school could not.

In the case of reading, it is clear that the State creates programs that should promote reading practices in the subject, and it is perhaps the exclusive task of the educational institution to promote this type of practice. The above shows that the school constantly steals the objectives and responsibilities of educational institutions. To avoid such responsibility, the educational institution commonly tends to prosecute the child who contradicts the norm and that shows the inefficiency of the organization and with it the teachers themselves. That is, the school is incapable of promoting the type of reading that the system itself imposes on it, there is no completeness in its entirety, that is why programs and policies that promote reading promotion campaigns are used.

Institutions are also defined as a social structure, as a concrete organization. Individuals are different in each institution, but so will the modalities of their relationships.

In the same sense, one more sense of institution is to consider it as a place of production and relations of production. In this case, production must be mediated by cultural capital. Institutional analysis has a multidisciplinary history that is rooted in both theories and philosophy. Some of its objectives are:

a) The search on the causes that hold together the individuals that constitute groups.

b) Develop psychological and sociological projects in the area of education in order to improve the ability to learn. 
c) Question rigidly instituted bureaucratic norms and the transformation of existing structures through methodological and ideological changes.

In itself "the institutional analysis is manifested as a practice based on a theory and an ideology, which allows to go in search of the institutional structural depth in an organization in a situation of conflict or crisis" (Butelman, 1994). In this way, the function of the institutional analyst seeks a change in the practice of the institution to which he belongs, which should lead him to voluntarily renounce his own knowledge, so that he can go through and capture the institutional object.

On the other hand, the institutional analysis seen only from the educational level, is an important point for the investigation of "reading practices", however, it provides a limited idea, because reading is not reduced to the school environment. In the investigation there is explanation and search for causes; hence, proposals are proposed where alternatives to promoting reading practices in children and teachers are suggested; To this end, it is important to discuss the bureaucratic norms established that drive reading promotion programs. And deepen the structure of the "reading practices" that occur in the school institution and in the family institution.

Thus, it must be recognized that the emergence of institutions implies a series of primary or secondary needs. In the former it refers to the basic needs for example of food, clothing, health and housing; the second ones refer to the symbolic: education, religion, etc. In these institutions the subjects inevitably play or play roles, functions, actions or roles characterized by the way in which the individual is constituted from his idiosyncrasy.

Consequently, the institutions are constantly seeking to generate a collective conscience based on the internalization of their own norms, rules, laws or premises. They have to create an ideological homogenization (make everyone think the same), that the form of organization of the institution is rooted to their mental structures and thus regulate the form of socialization. Where subjects are able to do the same.
Educational and family institutions impose a way of reading, an ideology of reading, that is, they assign ways and interests for which the subject must read. Which has been restricted to reading to learn certain school content, to read for study before an exam, etc.

So, it is inherent in institutions to reproduce forms of control or repression by the authorities; such control is lowered to other subjects by immediate subordinates to the highest authority, however, each institution does so with particular characteristics. In some, the form of control or domination is done in a fairly rigid and authoritative manner; in others it is carried out in a lighter and more subtle way and in others the dogmatic representation may be imperceptible to the subordinate subjects of the authorities.

Certainly, conceptualizing the term institution is confusing and ambiguous, as the analytical category takes multiple meanings. Defining it as "synonymous with social regularity referring to norms and laws that represent social values and guide the behavior of individuals and groups, setting their limits" (Fernández, 1995, p. 13), seems to be prudent, since it outline in a sentence what has been sold arguing. In that sense, the influence and impact that institutions can have on groups and subjects, will not be homogeneous, that is, it may vary according to the type of institution, according to the individual and the context external to the institution. The institution, under this vision, will be an organization in which its tasks will be regulated by a set of systems; Likewise, the groups that make up the institution will create a unique version of the models and general norms. Reading, seen from the institution, is a practice that introjects content and ritual ways of understanding the social imaginary and the symbolization of the act of reading at a given time in a specific community. So if you want to reflect on the pressures and conditions exerted by the institution or institutions in the configuration of reading practices, the following questions will have to be considered: what is the social regularity that the reading act is propitiated in the institution (family or school)? What are the limits of reading imposed on institutions? Although concrete answers to these questions are not supported, this is not an obstacle for the reader to think about and answer them for himself. 
However, a study conducted by CONACULTA (2006) on reading in Mexico indicates that the main reasons why people read are the following: a quarter of the population $(24.6 \%)$, read for being informed; following school grounds with $20.5 \%$. The natural taste for reading is referred to by $9.2 \%$; for fun, $6.8 \%$; Responses that refer to a dimension of individual improvement (personal growth $8.0 \%$, professional improvement $7.3 \%$, to be cultured $3.1 \%$ ) together reach $18.4 \%$.

Consequently, it is then confirmed that children and young people are reading mostly for accessing a type of information. Secondly, it is read for purely school reasons, both reasons are related, because it is read to know and then this knowledge is used in the school environment.

Therefore, the problem lies in the fact that the majority of children and young people are reading solely for school reasons, which restricts reading, which from school, becomes an instrumental reading, this idea of reading means that he reads by obligation and for fulfilling school tasks, which in the great majority do not transcend the social field because they are decontextualized from the immediate reality of the student, in that sense, the students carry out "stuttering" reading practices. becomes a means and not the end, reading thus serves the subjects only in the here and now.

Without a doubt, reading is thus a habit imprinted in the school institution, when conceiving it from habits it is restricted by minimizing it:

The writer Walter Foss tells a curious anecdote: one day a young calf, with an uncertain step, moves away from the farm until it reaches the nearby hill. The farmer, who has followed him with his eyes, goes after her after a while and following the same path ... A hundred years later, the locals still travel that route along the path that the old and clueless veal will trace.

Such becomes the weight of habits and the inertia of traditions! (Rodríguez, 1989).

\footnotetext{
${ }^{1}$ (Guadalajara, 1942) He is an editor, storyteller, translator and teacher (UNAM). For thirty years he has worked in the training of readers. He has directed the SeP's Reading Corners program. He is the author of How to Read Better Out Loud (Mexican Foundation for Reading Promotion).

It is true that everyone has habits: eating certain things on certain days, smoking, visiting or not visiting friends, attending such shows, etc. Subjects and institutions live on habits. The very concept of institution implies stability, because when a human group is more institutionalized, behaviors become more predictable and controllable. Reading as a habit is repetition, inertia, the known, the easy, implies security; Reading from practice is the change, the new, the risk maybe, the effort. Then reading as a habit will not transcend practice, therefore, reading as a habit from school is a reading that does not spread to the social context of the subject.

Another aspect is that, reading has also been seen in school as a means of production, and who produces as a reader is a person with a broad reading comprehension, however, this production refers to economic production, in that sense, giving the maximum in the shortest time, or rather reading the maximum in the shortest time, becomes the school flag. Reading should be seen as a production and reproduction of culture, and not limited to school, from the cultural can be rescued other types of productions.

Therefore, it is difficult to become a reader if there is no one to promote reading. Felipe Garrido ${ }^{1}$ and maybe many teachers have already checked. It is said that who reads by obligation both inside and outside the school is not a reader and, who reads outside the school and also inside it, and also does it for pleasure, is a person who likes to read, is a reader.

However, Cornelius Castoriadis (Castoriadis \& Pedrol, 2006) explains that institutions are validated in two ways: superficially with cohesion and sanctions -idea referring to the instituted character- and less superficially with accession, support, consensus, legitimacy and the belief-idea that refers to the instituting character-, however, gives the institution itself the possibility of making sense of the instituting. 
For this author the institution is made up of the norms, values, language, instruments, procedures and methods to deal with things and also has to do with the individual self, in the type and form, both particular and general that occurs in each society; It is remarkable how Castoriadis gives special importance to the context where the institution is gestated, since for him society will always be of a historical-political nature, in such a way it can be established that also the practices, in this case of reading, will be so.

It should be added that, the institution from the perspective of this thinker, largely coincides with what Paolo Virno (2004) manages, both assert that the institution will always have a dynamic character, since if the basis of society is the institutions and society itself has a dynamism according to the time in which it is located, it will have the characteristic of having a changing structure, in order to have the ability to adapt to the context consistent with the culture of historical-political-cultural time to which it belongs. In that sense, reading becomes a practice embodied in certain gestures, spaces and habits.

There are no specific ways of reading. All those who establish a relationship with the text, who can read it, do not do it in the same way. And in every age the reading perspective changes, the difference between the learned and the clumsiest readers is great. Contrasts, finally, between rules and reading conventions that, in each community of readers, define legitimate uses of the book, ways of reading, instruments and interpretation procedures. And in contrast to the hopes and interests so heterogeneous that the various groups of readers put into practice reading. According to Chartier (1998), on these determinations, which govern the practices depend on the ways in which texts can be read, and read differently by readers who do not share the same intellectual techniques, the same cultural habits, lifestyles, same values, and therefore do not maintain a similar relationship with the written, hence they do not give the same meaning or the same value to a seemingly identical gesture: read a text.

On the other hand, the concept of institution provided by Castoriadis (2006), shows that the subject is co-producer of these and transcends the fragmentary vision of Lidia Fernandez (1995).
The perspective on Lidia Fernández's institution is essentialist, fixed and deterministic, and unable to realize that the institution is creative, as handled by Virno and Castoriadis. Thus, reading is based on the collective social imaginary of Castoriadis as handled by Chartier (1998), when he states that there are no specific modes of reading and therefore, reading is a practice that is not ahistorical, but has a history that has been delimiting it.

When defining the institution as a social regularity and support of social life, it is also very important to identify in the dynamics of the institutions the world of the symbolic, since it is in the symbolic where the meanings are constructed to the material world (inseparable characteristic to the concept of institution). In this way it is possible to analyze the reason for certain behaviors of individuals under certain conditions impregnated with the symbolic.

When an institution (group, society) causes experiences of fear and pain to the individual, such as rejection, banishment, punishment; or, experiences of approach or fear of reading, the individual will evoke experiences or primary meanings. Therefore, institutions are still understood as meanings that seek to direct the behavior of individuals towards the acceptance of certain models of authority, of certain concrete models of reading.

Within the institutions there are organized cores of behavior. In institutions, the individual must set aside the desire, since it dislodges it, projects it; He must act under the morality that is being imposed on him in order to reach a balance. Institutions, then, function as a space for the concretion of what is instituted, accepted, established. The reading practice is thus established as a mere academic requirement to pass a certain course, this is instituted both in the family institution and in the school institution. Although the institutions are spaces of submission and acceptance of rules and norms, the deviant factors enrich the instituting part since they propose different aspects to the instituted. Therefore, the deviation is always positive because it expresses common problems. Hence, a reading community always has processes and practices of anomaly and transgression. 
According to Lidia Fernández (1995), deviants are also known as disruptors, who create discomforts and conflicts in the institution and also come loaded with positive elements and create some prosperity. Although certain molds of reading practices are imposed and instituted on the subjects by the different institutions they are going through, there will always be an institution that breaks with these imposed reading practices, in this sense the meanings of reading adopted in the family or society, they will gain weight in other spaces, and may manifest themselves in an instituting behavior.

In this sense, the same author also mentions two very interesting concepts with what can be understood in a better way the organization of the educational institution: "Valencia and resonance" (Fernández, 1995). Both concepts are related to the role played by a subject within a group, valence refers to the impact it has within an institution, in this case the educational one, a subject in relation to the other members, also corresponds to the causes that they make certain types of people popular (way of dressing, speaking, etc.). The resonance has to do with the influence that is exerted towards certain people of the institution to which it belongs, therefore, to resonate means to impregnate our groupmates of our cultural patterns and reading practices.

It is for the above that within the establishments, seen as institutions, adhesion or liaison links are generated, resulting in a collective conscience being generated. However, this idea of collective consciousness is not synonymous with ideology, since institutions do not fully determine ideologies, it is determined by context, social, etc. In this tenor, ideology is a social recreation where institutions participate. Within the institutions, the subjects are in relations of production and significance, so it will also be in relations of power. That is why, the subjects are always in search of power, it is an attitude of the same human nature, that power is usually sought through institutions. However, to that search for power, according to Fernández (1995), negative consequences are attributed to it, as they cause discomforts, conflicts and crises that can lead to a setback; for example, in the family institution divorce is generated almost always caused by a crisis, this situation is triggered because one of the parties wants to take control of the relationship, seeks dominance, power.
Likewise, reading and writing are forms of domination - although they are also a source of creation, resistance and empowerment. Throughout the book History of reading in Mexico (1999) it is mentioned that since time immemorial, reading has represented forms of power and social control. In the evangelization of New Spain, the sword and the cross were the symbols of the conquest at the times when New Spain was born, next to the sword came the pen of the scribes, royal officials and jurists; and very close to the cross was the book, or the books of revelation. Reading was instituted as a form of power and domination, and only for a few, for the children of caciques and children gathered in the convents that later became prosecutors and teachers, consolidated their prestige by being considered as superior to the rest of the population . The Indian was subjected by learned people, thanks to the practice of reading, power and control were thus exercised.

On the other hand, Michel Foucault (2005) goes further in analyzing power. He maintains that power is developed in relationships, therefore, relationships are power relations. By taking a series of oppositions that have developed in recent years: the opposition of man's power over women, that of parents over children, of psychiatry about mental illness, of medicine about illness. All of them, according to Foucault, share something in common: they are transversal struggles; that is, they are not limited to one country; The aim of these struggles are the effects of power itself. These forms of power emerge in everyday life, categorize the individual, mark him in his own individuality, unite him to his own identity, a law of truth that he has to recognize and at the same time others must recognize in him. The reading practices that come from the subject in their diverse contexts are the result of the power relations that are generated in the family institution and educational institution. The subject is defined, based on Foucault's arguments, as: subject to another by control and dependence; and subject as constrained to his own identity, his consciousness and his own self-knowledge. Both meanings suggest a form of power that subdues and constitutes the subject.

For Foucault, reading has played a key role in shaping subjectivation games in the West, basically reading has been a hermeneutic of thinking about the world, the body and the relationship with itself. 
The ontology of the present is an appropriation of our interpretations at the service of the event that embodies the constitution of a here and now as vectors of intelligibility of the subject itself.

The relationship that the subject establishes with the reading could be defined depending on the contextual plane in which it is located. For example, the subject carries out the reading practices in the school from a control and a dependency, which leads him to reproduce an instrumental reading, that is, to read halfway, to simulate the reading and to limit himself to read textbooks; The reading is usually located only at this level. On the other hand, at the family level, reading practices are carried out based on subjectivation, that is, it is read from the cultural capital that the subject has received from the social structure of which he is co-producer. That is why it is said that he could read or not read, from submission to his own identity, to conscience and self-knowledge.

Following the analysis of the concept of institution, Lucia Garay (cited by, Butelman, 1998) argues that in the institutions there are discomforts, conflicts and crises. It should be noted that you should not think about the discomforts, crises and conflicts as synonyms, since each one has particularities that make them different. Lucia Garay differentiates each element from the following premise: discomfort occurs on an individual level, the conflict is mediated by two or more people and the result of this summary is the crisis; transformation, evolution and change process. It could be affirmed that to define institutions more broadly, it is necessary to take into account the malaise, conflicts and crises as three phenomena constituting the institutional dynamics that refer, in their origin and meaning, to the relational game of three basic and constitutive instances.

In that sense, Lucia Garay defines the institution as culture, where borders are determined, more or less precise, more or less permeable, between inside and outside, decides on the elements that integrate it, on strangers; receives mandates and demands; demand in turn; generates projects, plans and programs; build an organizational structure, install procedures and routines; favors or hinders processes of change generates mechanism or modes of conflict regulation (cited by, Butelman, 1998).
Now, with the sedimentation of styles, an institutional culture is produced. A culture of reading is reproduced in the subjects, a culture subject to an ideology built or imposed to some extent by the educational and family institution. Lucia Garay articulates many of the concepts of the authors previously presented to define the institution. The majority agree that the institution is a system of values, ideals and norms. Not all subjects have the same ideology, although collective consciousness is part of it, each one also constitutes it from subjectivity; Therefore, there are some who are destined for their way of thinking to be submissive and others to take the lead, to be instituting people, or focusing it on the practice of reading, reading or not reading. The ideology then determines the social role played by the subject within the institution.

In the same way, it is important to take into account all the concepts contributed by the different theorists about the concept of institution, as this will allow to understand the establishments (educational or non-educational) from the analysis of the systems of relationships, of the form of organization, of the type of structure, of the forms of domination and control, of the meanings that individuals and subjects are building throughout the trance in the institution. Institutions are a pillar and basis for analyzing reading from practices, as it is in institutions where culture, habitus, ideology is gestated and subjective. The family institution, school, society, are the ones that set the tone for social agents to do or stop doing certain things, certain institutionally introjected practices.

\section{Identity, subject and subjectivity}

For Foucault (2005), subjectivity is not unique. Each era has a historical mode of subjectivation. Because in each notion of subjectivity the distributions of political power that correspond to the historical moment in which they were built are articulated. Subjectivity is the way in which the subject makes the experience of himself, but that experience is not the same for everyone, it is the experience of the particular world in which one lives. In each historical moment, individuals are building different forms of subjectivity. In this way, reading represents an experience that the subject makes of himself, evokes reading practices from the particular world of which he lives. 
In this scenario, subjectivity is a factor that influences the way in which the subject perceives, feels, experiences, means, etc.

Reading practices Each subject will therefore have a different vision and perspective on reading at a given historical moment.

Certainly, if reading were forged as a way of life, the subject would be engaged and immersed in an environment where the newspaper circulates, read aloud, where stories are also read, various magazine articles are commented, etc. Institutions, as Lapassade (1977) understands them, are systems of rules that largely determine the construction of subjects as reading subjects, as subjects that maintain social relations around the practice of reading, subjects that generate perishable reader practices or ephemeral, or managers of practices where reading is a way of understanding the environment and the world. The institution family, school, club, or any other group, play a fundamental role in the formation of subjectivities that lead students to learn from reading as their world and form that idea of the world. Since, reading shapes subjectivities, subjectivity is constructed from the link with the imaginary social meanings and the cultural symbolic order, which makes it possible to give meaning to the real. Sense that embodies and constitutes the subjects (Ramírez, 2005a). From the reading practices two subjective visions can be configured with respect to the world: that of illiterate people, who limit themselves to defining it based on their own experiences and; that of the literate people who define it from many perspectives, based on a subjectivity forged in reading and that also continues to be formed to approach reading as an element to understand and understand the world. Thus reading as an idea of the world in the subject leads him to conceive it, precisely, as his world, as a way of life that also allows him to adopt a vision in front of the social, political, cultural and natural world.

For his part, Raymundo Mier (2003), argues that the notion of subjectivity runs an equivocal fate: it was offered at the same time as reason and as twilight, as the ultimate reference of knowledge and as mist. It is complex then to fully define the term. Contemporary trends put into play a multiplicity of reflections and concepts that involve in a diverse way, even antagonistic, the notion of subjectivity.
In sum, there is no univocal definition of this term, there are different visions about it. It is necessary to conceive subjectivity as the set of perceptions, images, sensations, attitudes, aspirations, memories, and feelings that drive and guide the actions of individuals in the permanent interaction with reality and, specifically with reading. For the reading subject, this whole set would be the meanings that lead him to read and what the interaction with the reading means in relation to the reality he lives.

In relation to identity, this is an inherent element of subjectivity, Raymundo Mier (2003) mentions that there are various ways of defining identity, on the one hand it can be seen as one of the essential features of being; and on the other, relying on other philosophical positions, it is affirmed that it is precisely the possibility of variation and modification (that is, the absence of identity) that characterizes the true being. They are two contradictory positions, however, they are part of a social historical process that adds, removes or contradicts what is stipulated in certain concepts. Just as the identity of the subjects changes, so does the meaning given to define it.

The issue of identity becomes relevant, since it is from this analytical category that questions such as: Who am I? And who am I in front of the other? (Who am I as a reader? And who am I facing the other as a reader?). Without a doubt, argues Mier (2003), we are because of our history, our practices (in this context, we are readers based on our reading practices), and the collective meaning that they acquire, these evidences are reflected in the forms of to do, to speak, to think about conceiving the world of organizing their lives in spaces and times

Therefore, addressing subjectivity allows us to identify representations, fantasies, desire, the unconscious that leads the subject to read; with the objective of analyzing and interpreting the subjective elements that are present in the practice of reading, also recognizing the meaning and meaning that subjects give to reading.

However, it is necessary to recognize that subjectivity is "built from the link with the imaginary social meanings and the cultural symbolic order, which makes it possible to give meaning to the real" (Ramírez, 2005b). 
In everyday life, the term subject is used as well as that of person or individual, however, each one has its thesis, density and specificity, and it is of utmost importance for investigations of educational or other dye, distinguish them according to meaning that each one possesses.

In this sense, Beatriz Ramírez (2005b) argues that the term individual refers to an organism formed as a unit resulting from the total sum of cells, tissues, devices and systems that, organized in pre-established functions, constitute a living being whose characteristics They endow it with a singularity. Person is every human being, by the fact of being it, considered as a moral being, endowed with rights, cannot be treated as a thing; the person is the way in which the subject presents himself to others, it is the mask with which he acts.

The subject on the other hand is more complex, for structuralism is the creature generated by the action of the specific structure on a certain substrate or support. It is the effect of the previous structure and founding of its existence. Without the structures of which it is support, he would not exist as a subject. Ramírez (2005b) comments that the conception of the subject of which Lacan speaks, is different from that held by Foucault, Lévi-Strauss or Althusser because the theoretical and problematic categories referred to by each of them are different. However, all in essence share the idea of subjecting to a structure.

It is necessary to recognize that the bet of the human sciences is that of objectivity. It is about them to imitate the model of the natural sciences, and for that reason the man is contemplated from the pretension to reduce it to object of knowledge.

However, what will characterize the philosophical inquiry is the attempt to keep it in its character as a subject, remembering again and again that the reductionist simplification of it that characterizes the scientific approach does not exhaust all the dimensions that constitute us, and therefore, they should not presume that their results say what man really is, since his object of study has never been and cannot be man as such, but man as such or that aspect, that is, a falsification (necessary to adapt to the scientific method).
Not paying enough attention to this aspect has often caused them to fall into the excesses of pretending to fully explain man, magnifying the importance of some or that particular aspect: believing that man can be fully explained by reducing him to his socioeconomic conditions, or his drives natural, or its genetic code, its cultural environment, etc.

In sum, these paragraphs try to explain the reading based on the practices of the subject, and not the process itself. The process explains from a scientific point of view, this idea of seeing the process from a quantitative and objective point of view is discarded in the institutional analysis, since, for the theorists of these themes, the processes do not always meet scientific or objective conditions. Dilucidate reading from the practice dimension, forces us to see humans, not as an individual or as a person, but rather as subjects, in this way the dimensions are not exhausted and the parcel is not read as a biological mental process On the contrary, a fan opens that allows the analysis of the subject's reading practices based on a social, cultural, political and economic explanation.

In effect, the subjects are constituted by the structures and at the same time become support. Likewise, the subjectivity of a subject is constituted from the others with whom he identifies and whom he takes as models or as objects of love, internalizes them, and makes them part of his instances. It should be noted that this other is not exactly a person, but a place organized in the form of a network. Thus the identity of the subject depends on the recognition of the other, another that is also subject. The network of symbolic relationships is the other, the other seen as reading practice (Ramírez, 2005b).

In this regard, it is necessary to analyze how the subjective subject reading (subjectivation is shaped and ordered from the relationship with others) and how the objective; that is, how the individual is constituted and recognized as a reading subject; and how it shows or reveals itself to reality. It will be necessary then, to resume the modes of subjectivation, or as Foucault would call them: "dividing practices" (cited by, Marulanda, 2007). Which claim that the subject is divided both inside and divided from the others. This process the objective. 
Examples are the crazy and the sane; the sick and the healthy; the criminals and the good guys; The reader and the non-reader. Foucault also studies the ways in which human beings transform themselves into subjects. For example: how men have learned to recognize themselves as subjects of sexuality. The relevance of retaking it is due to the importance of retaking how men have learned to recognize themselves as reading subjects. The subject, subjectivity and institution, are elements that allow us to understand the phenomenon of reading practice from a cultural perspective.

\section{References}

Butelman. (1994). Psicopedagogia institucional. Argentina: Paidos.

Butelman. (1998). Pensando las instituciones. Barcelona: Paidos.

Castoriadis, C., \& Pedrol, X. (2006). Escritos Políticos: Los Libros de la Catarata.

Chartier, R. (1998). Historia de la lectura en el mundo occidental (segunda edición ed.). Madrid: SANTILLANA.

\section{CONACULTA. (2006). ENCUESTA NACIONAL DE LECTURA. México: CONACULTA.}

Fernández, L. (1995). El análisis institucional en la escuela. Barcelona: Paidos.

Foucault, M. (2005). La hermenéutica del sujeto: Ediciones Akal.

Lapassade. (1977). Grupos, organizaciones $e$ instituciones. Barcelona: Granica.

Lourau. (1970). El análisis institucional. Argentina: Minuit.

Marulanda. (2007). Michel Foucault: Interconexiones de Poder y de Conocimiento: Editorial LEIRIS.

Merlo, M. A. P. (2007). Lectura Informativa: Entrenamiento Escolar y Metacognicion: Editorial Universitaria.

México, H. d. 1. 1. e. (1999). Historia de la lectura en México. Mexico: El Colegio de México.
Mier, R. (2003). Tras las huellas de la subjetividad (2da ed.). México: UAM.

OCDE. (2011). Panorama de la educación 2010: Indicadores de la OCDE. España: Santillana, Spain.

PISA 2006 Competencias científicas para el mundo del mañana: Competencias científicas para el mundo del mañana. (2008). Santillana, Spain.

Ramírez, B. (2005a). Subjetividad y relación educativa. México: Universidad Autónoma Metropolitana.

Ramírez, B. (2005b). Subjetividad y relación educativa México: UAM.

República, M. P. d. 1., Pública, M. S. d. E., \& Artes, C. N. p. 1. C. y. 1. (2004). Programa Nacional: Hacia un país de lectores: SEP.

Rodríguez, M. (1989). Manual de Creatividad: los procesos psíquicos y el desarrollo (segunda ed.). México: Trillas.

SEP. (2001). Programa Nacional de Lectura. Retrieved from http://lectura.dgme.sep.gob.mx/

SEP. (2009). Plan de Estudios. Educación Básica. Primaria. México, DF: SEP.

Virno, P. (2004). Palabras con palabras: poderes y límites del lenguaje: Paidós. 